\title{
Potential impacts of climate change on natural and managed discharges of the Rivers Spree, Schwarze Elster and Lusatian Neisse, Central Europe
}

\author{
I. Pohle ${ }^{1}$,H. Koch ${ }^{2}$, A. Gädeke ${ }^{1}$, M. Kaltofen ${ }^{3}$, M. Schramm ${ }^{3}$, \\ M. Redetzky ${ }^{3}$, F. Müller ${ }^{3}$, U. Grünewald ${ }^{1}$ \\ ${ }^{I}$ Chair of Hydrology and Water Resources Management, \\ Brandenburg University of Technology Cottbus - Senftenberg, Germany \\ ${ }^{2}$ Research Domain Climate Impacts and Vulnerabilities, \\ Potsdam Institute for Climate Impact Research, Germany \\ ${ }^{3}$ Branch Office Dresden, DHI-WASY GmbH, Germany
}

\begin{abstract}
The water balance of the Rivers Spree, Schwarze Elster and Lusatian Neisse is profoundly disturbed due to large-scale open-cast lignite mining activities and water management. Together with continental climate conditions this affects water resources and water users in the region. Driven by scenarios of the regional climate model STAR which assume increasing temperature and decreasing precipitation, two hydrological models, the Soil and Water Integrated Model SWIM and the catchment model EGMO simulate declining natural discharges in the region. Thus, decreasing managed discharges are simulated with the long term water management model WBalMo. The refinement of the simulation time step of WBalMo from months to weeks improves the consideration of climate variability and is also associated with higher simulated managed discharges in early summer. Management scenarios in terms of a reduced outlet capacity of a mining lake reservoir result in higher releases from other reservoirs and slightly reduced summer discharges in downstream river sections.
\end{abstract}

Keywords: water management modelling, hydrological modelling, climate change, mining. 


\section{Introduction}

The impact of climate change on water resources is of fundamental concern [1, 2]. It is of essential interest, whether climate change impacts can be mitigated by adaptation of water management [3]. Potential future developments can be quantified by modelling of climatic changes and their impacts on hydrology and water management [4]. As uncertainties propagate in the model chain, multimodel ensembles are commonly used in climate change impact studies [5].

The spatial resolution of global climate model (GCM) outputs is too coarse to be used in regional hydrological modelling [6]. Therefore, the use of climate data on a regional scale requires the regionalisation of data delivered by GCMs using a Regional Climate Model (RCM). For this analysis data from the GCM ECHAM5/MPI OM [7] were regionalised by the statistical RCM STAR [8, 9]. To account for the impacts of climate variability and also uncertainties related to the hydrological model used, for each scenario 100 realizations of climate input were used to simulate natural discharges by two conceptionally different hydrological models, SWIM [10,11] and EGMO [12, 13]. Water management is simulated by the software 'Interactive Simulation System for Planning and Management in River Basins' WBalMo ${ }^{\circledR}$ (Water Balance Model, WBalMo ${ }^{\circledR}$ is a registered trademark of DHI-WASY Ltd). Within this study project, the simulation time step of WBalMo was refined from months to weeks.

The main objectives of this study were to assess potential climate change impacts on natural and managed discharges. Also, it was analysed how the refinement of the simulation time step of WBalMo influences simulation results. The variation of the outflow capacity of the mining lake Lohsa II Reservoir is discussed as a measure of climate change adaptation: In summer months this reservoir is used for low flow augmentation. Due to the low $\mathrm{pH}$ and high iron and sulphate of the water in the reservoir, the aim is to decrease outflow per time step so that to water quality of the Spree River is not too much affected. A favourable side effect is that the less water is released from the Lohsa II Reservoir in spring, the more water is stored until summer and might be used for low flow augmentation.

\section{Data and methods}

\subsection{Study region}

The study region (fig. 1) includes the catchments of the Schwarze Elster River (catchment area ca. 5,500 $\mathrm{km}^{2}$ ), parts of the catchments of the Spree River (entire catchment area ca. $10,000 \mathrm{~km}^{2}$ ) and the Lusatian Neisse River (entire catchment area ca. 4,300 $\mathrm{km}^{2}$ ). The catchments comprise parts of Germany, Czech Republic and Poland. Schwarze Elster River and Spree River are tributaries to the Elbe River, while Lusatian Neisse is a tributary to the Odra River. Lusatia is characterised by a continental climate: due to low annual precipitation and relatively high summer temperatures the climatic water balance is negative for many parts of the region. Therefore, reservoirs are used for low flow 
augmentation and drought mitigation for wetlands. The Bautzen Reservoir and the Spremberg Reservoir are located on the Spree River; the Quitzdorf Reservoir is located on a tributary of the Spree River.

Large-scale open pit lignite mining activities affect water quantity and water quality in the region. To produce lignite in open-pit mining, ground water resources have been pumped resulting in a groundwater depression cone of more than $2,000 \mathrm{~km}^{2}$ in 1989 [14]. The pumped mining water is used as cooling water in thermal power plants or released into the river system. At closure, mine dewatering ceases, and due to inflows from both surface water and groundwater, the water level starts to rise in the open pits so that mining lakes are formed. Due to pyrite and marcasite oxidation associated with mining the water quality of these mining lakes is characterized by low $\mathrm{pH}$ values and high iron and sulphate concentration. One of these mining lakes is the Lohsa II Reservoir. It is connected by a bypass to the Spree River so that its inflow can be controlled based on the storage content of the reservoir.

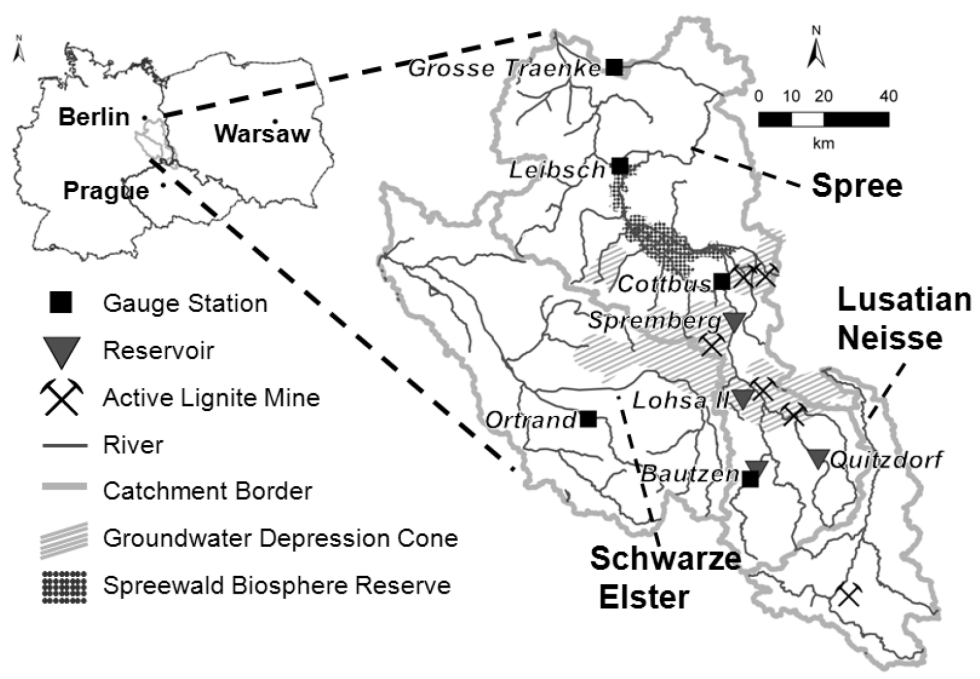

Figure 1: Study region including reservoirs and gauge station and the current state of the groundwater depression cone.

\subsection{The regional climate model STAR}

The STAR algorithm resamples segments of regional climate data sets, e.g. air temperature, relative humidity and precipitation on a daily basis forced by a linear air temperature trend. The realistic description of annual cycles and persistence are ensured by heuristic rules for the resampling [9]. The climate change signal used in this study is based on the GCM ECHAM5. In this analysis, 100 realizations each of scenarios assuming a further temperature increase of $0 \mathrm{~K}$ (STAR 0K), $2 \mathrm{~K}$ (STAR 2K) and $3 \mathrm{~K}$ (STAR 3K) in the region until 2055 are 
used. In the region, increasing temperature is associated with decreasing precipitation (by about $6 \%$ in STAR $2 \mathrm{~K}$ and $9 \%$ in STAR $3 \mathrm{~K}$ ).

\subsection{Hydrological modelling with SWIM and EGMO}

The Soil and Water Integrated Model SWIM is a process-based ecohydrological model which simulates the hydrological processes as well as crop growth and nutrient cycling spatially semi-distributed based on hydrotopes. The hydrological processes included in the model are potential and actual evapotranspiration, snowmelt, surface runoff, subsurface flow, groundwater flow and flow routing. A detailed description of SWIM can be found in [11]. As such, SWIM has been used in various climate and land use change impact studies, especially in Germany and in the Elbe River catchment $[15,16]$. In this study, an enhanced ground water module and an approach which allows vegetation to access river discharge in riparian zones taken from Conradt et al. [16] were used. As the traditional approach of model calibration is constrained by anthropogenic influence on the discharge, the model SWIM was first calibrated for subcatchments with minor influence of mining and water management [17]. The models for the entire catchments were parameterized by regionalization [18].

The catchment model EGMO is a conceptual rainfall-runoff model which describes catchments based on their characteristics of deep and shallow groundwater and open water surfaces. The model simulates the processes of overland flow, interflow and base flow. Snowmelt and potential evaporation have to be accounted for in the pre-processing. EGMO has been used in various studies on a monthly time step especially for generating stochastical time series of discharge as input data for long term water management [19, 20]. For this study, the time step was refined from months to weeks.

In order to account for the large groundwater depression cone, where percolation fills the groundwater deficit in these areas, subsurface and groundwater flows are set to zero for these areas in both hydrological models. The future development of the groundwater recession was considered by a scenario which assumes that all mining activities will cease by the year 2050 . The management of lakes, reservoirs and the largest wetland in the region, the UNESCO biosphere Spreewald, are included in the long term water management model WBalMo and therefore are not considered in the hydrological models. Both hydrological models were driven by climate variables STAR scenarios.

\subsection{Long term water management modelling with WBalMo}

The long term water management modelling system WBalMo is based on volume-balance accounting procedures for tracking the movement of water through a system of reservoirs and river reaches. Water is allocated in the river basin according to priorities. Further information about WBalMo is given in Kaden et al. [20, 21]. WBalMo has been applied on the monthly time step in several projects, mostly within the Elbe River catchment [19, 22, 23]. On the basis of the modelling system WBalMo a model called WBalMo Spree/Schwarze Elster has been developed by the water authorities of the 
German federal states Saxony, Brandenburg, and Berlin and the Lusatian and Central German Mining Management Company (LMBV) for the catchments of the Spree River, the Schwarze Elster River and the Lusatian Neisse River. It includes the future development of lignite mining and demand of water users, e.g. thermal power plants. Further information on the WBalMo Spree / Schwarze Elster can be found in Kaltofen et al. [24] and Koch et al. [19]. The model was made available to the project partners and has been further developed within the project: To improve the consideration of climate variability, the simulation time step of the model was refined from months to weeks. In this study, the inputs to WBalMo are natural discharges simulated by EGMO and climatic variables necessary to calculate evaporation of lakes and reservoirs depending on their water level. Climate change adaptation measures are analysed in terms of management scenarios of the mining lake Lohsa II Reservoir. In these management scenarios, the maximum outlet capacity of the Lohsa II Reservoir is reduced from $7 \mathrm{~m}^{3} / \mathrm{s}$ (reference) to $5 \mathrm{~m}^{3} / \mathrm{s}$ (C5) and $3 \mathrm{~m} / \mathrm{s}(\mathrm{C} 3)$ with the aim of releasing less water per time step for water quality reasons.

\section{Results and discussion}

The results will be shown as mean values for 5-year periods from 2013-2052. They will henceforth be referred to as their central years, e.g. 2015 for the period 2013-2017. Unless otherwise stated, the results refer to simulation results of WBalMo on a weekly time step based on simulations for natural discharges of 100 realizations of STAR $2 \mathrm{~K}$ and EGMO.

\subsection{Impacts of climate change on natural discharges}

For two catchments without influence of water management and mining activities, the Spree River up to gauge Bautzen and a tributary of the Schwarze Elster River, the Pulsnitz River up to gauge Ortrand (see fig. 1), natural discharges simulated by SWIM (STAR 0K, 2K, 3K) and EGMO (2K) are shown in figures $2 \mathrm{a}$ ) and $2 \mathrm{~b}$ ). Due to 100 realizations of potential climate variables high bandwidths of potential natural discharges are generated. For both catchments, highest discharges are simulated in the $0 \mathrm{~K}$ scenario for which the medians do not vary over time while for the other scenarios declining discharges are simulated. Despite only slight differences between absolute discharges values of the two hydrological models in 2015 for Bautzen, EGMO simulates higher discharge for Ortrand in this period. Therefore, the relative change in discharge compared to simulation results of 2005 of the respective hydrological model and scenario is of interest (fig. 2c), d)). Notably, driven by the same climate scenario $2 \mathrm{~K}$, the relative decrease in discharge is more pronounced for the simulations of EGMO than those of SWIM. 

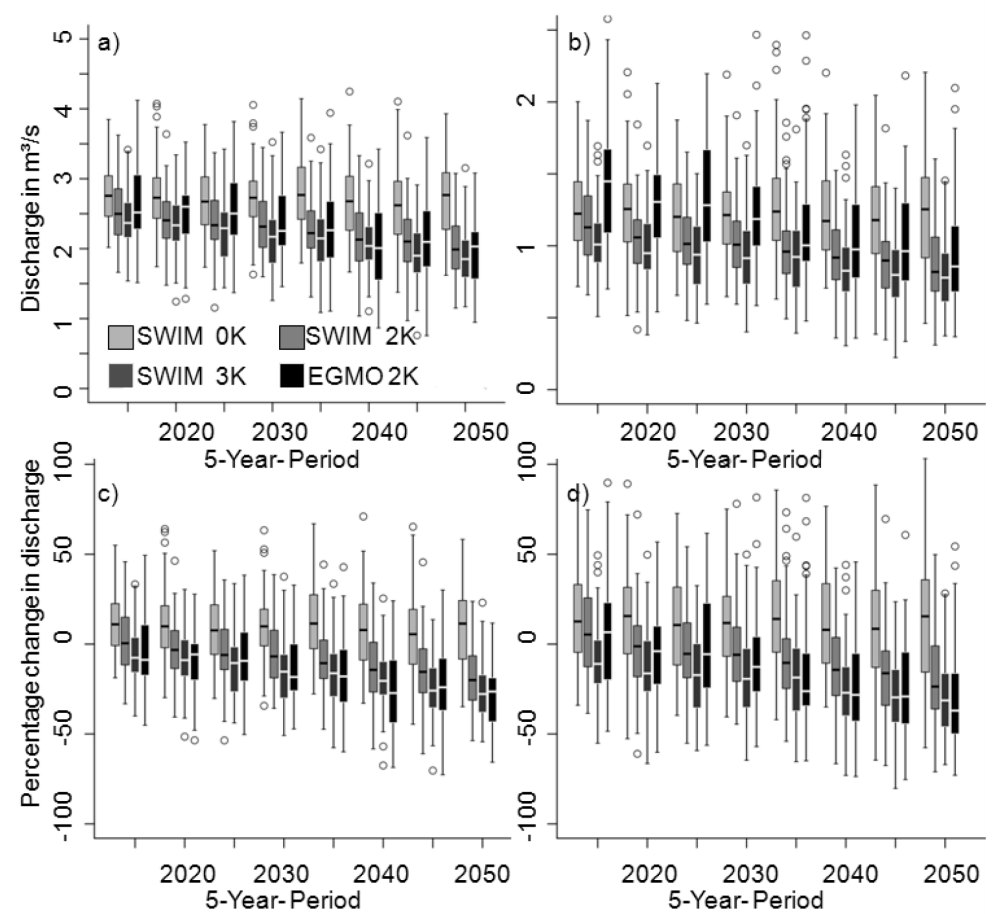

Figure 2: Simulation results (means of 100 realizations each in 5-yearperiods) of SWIM $(0 \mathrm{~K}, 2 \mathrm{~K}, 3 \mathrm{~K})$ and EGMO $(2 \mathrm{~K})$, natural discharges a) Bautzen; b) Ortrand; changes in natural discharges c) Bautzen; d) Ortrand.

\subsection{Impacts of climate change on managed discharges}

Due to lower natural discharges caused by climatic changes also decreasing managed discharges are simulated (fig. 3). Until 2030 this is counterbalanced
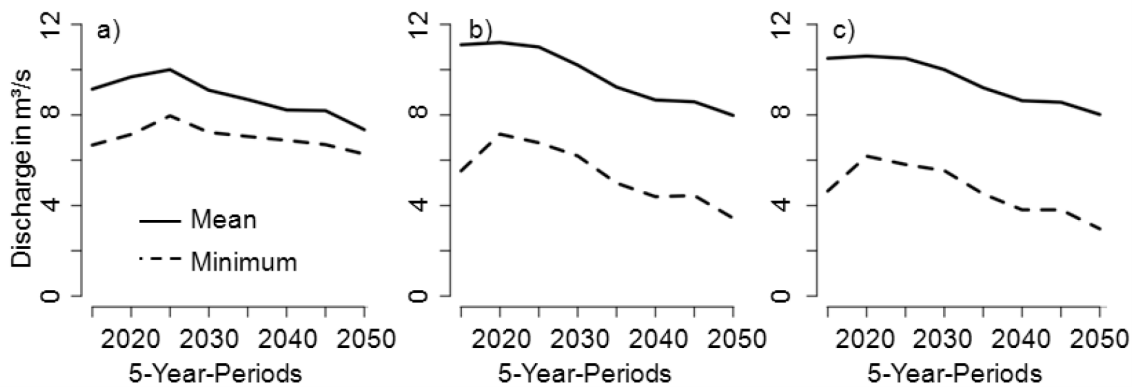

Figure 3: $\quad$ Mean and mean annual minimum managed discharge for the 5year-periods, a) Cottbus; b) Leibsch; c) Grosse Traenke. 
due to the decreasing groundwater depression cone. For gauge Cottbus (fig. 3a)), the small difference between annual mean and mean annual minimum shows the strong influences of water management on this gauge. For gauge Grosse Traenke (fig. 3c)) the minimum discharge constantly falls below the required discharge of $8 \mathrm{~m}^{3} / \mathrm{s}$. In the middle of the century even the annual mean reaches this limit.

\subsection{Influences of the simulation time step}

The refinement of the simulation time step from months to weeks improves the consideration of climate variability. This results also in higher variations for the managed discharges, visible even when considering mean weekly values of fiveyear-periods (fig. 4). For subcatchments without water management, e.g. the upper Spree catchment up to gauge Bautzen (fig. 4a)), if the simulation results on a weekly time step are aggregated to months, these values do not differ from simulation results on a monthly time step. In the water management simulation, maximum outlet capacities constitute a threshold for the respective simulation time step. That means, in the weekly time step these thresholds are reached only for those weeks with higher than average discharge but in the monthly simulation time step, they are reached for an entire month. Therefore, for river sections controlled by a maximum reservoir outlet capacity, the values simulated based on a monthly time step exceed monthly values based on a weekly simulation. Especially for gauge Cottbus (fig. 4b)) the differences between
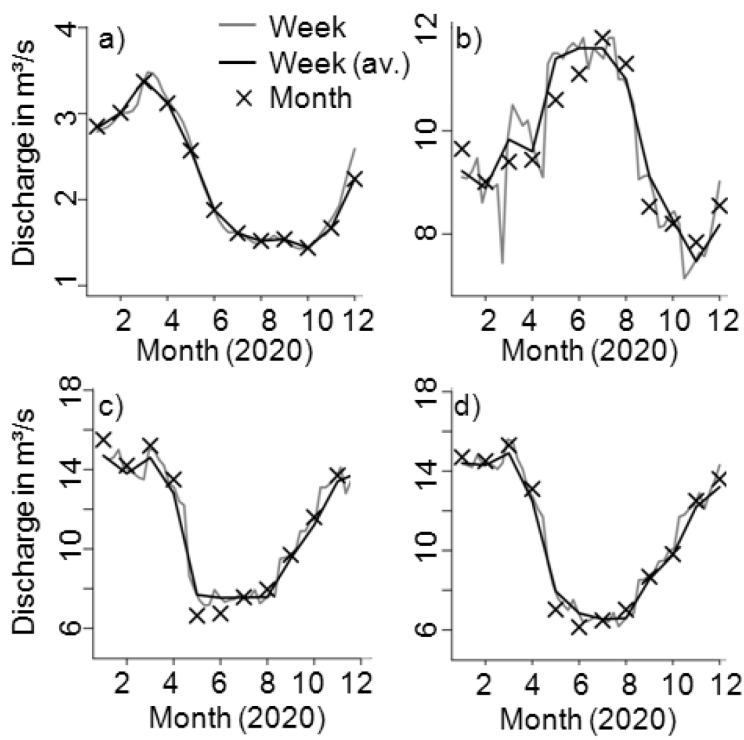

Figure 4: $\quad$ Simulated discharges for weekly simulation time step, monthly averages weekly simulation time step and for monthly simulation time step, mean values of 100 realisations of STAR $2 \mathrm{~K}$ and EGMO in the 5-year-period 2020. a) Bautzen; b) Cottbus; c) Leibsch; d) Grosse Traenke. 
results on a monthly simulation time step and monthly averaged from weekly time step are remarkable: The discharges on a monthly time step are lower than the monthly averages from weekly time step in spring and early autumn, but higher in January, July and August. For Cottbus, also the annual cycle of managed discharges is very different from the other gauges: the summer discharge here is very high, as a result of releases from reservoirs to augment low flow discharges downstream and also for drought mitigation in the Spreewald wetland upstream of gauge Leibsch. Managed discharges in the winter months are comparable low for Cottbus as then the natural discharges are used to fill the upstream reservoirs. For gauges Leibsch and Grosse Traenke (fig. 4c) and d)) discharges in early summer step are slightly higher on a weekly time than on a monthly time step.

\subsection{Adaptation by variation of the outlet capacity of the Lohsa II reservoir}

The impact of the change of the maximum outlet capacity strongly depends on the relative storage volume: if the reservoir is nearly empty, the impacts of the reduction of course are negligible. Therefore, one year with comparable high reservoir storage throughout the year (year 2022 of realization 4) was chosen to illustrate the impacts (fig. 5). The reduction of the maximum outlet capacity of the Lohsa II Reservoir from $7 \mathrm{~m}^{3} / \mathrm{s}$ (Reference) to $5 \mathrm{~m}^{3} / \mathrm{s}(\mathrm{C} 5)$ or $3 \mathrm{~m}^{3} / \mathrm{s}(\mathrm{C} 3)$ in the management scenarios is associated with lower outflow from the Lohsa II Reservoir. Consequently, for the management scenarios with reduced outlet capacity also the storage content decreases to a lesser extent. Therefore, the reservoir can be used to increase low flow discharge also in early summer (week 25 ), which is possible only for the $\mathrm{C} 3$ scenario in this example. As the Lohsa II Reservoir is filled by a bypass of a tributary of the Spree River, its inflow is controlled by the relative storage volume. Therefore, as the storage volume for the $\mathrm{C} 5$ and the $\mathrm{C} 3$ scenarios is higher, the inflow is reduced compared to the reference and the water that could flow into the reservoir bypasses it instead.
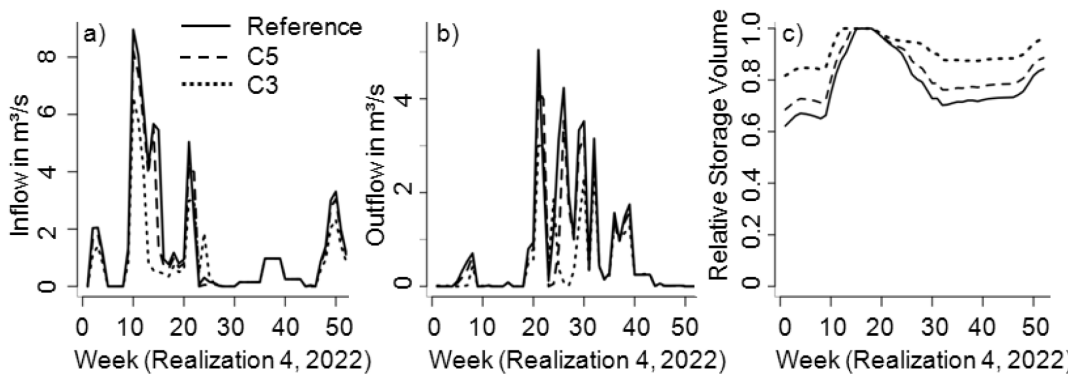

Figure 5: Simulation results for the mining lake reservoir Lohsa II on a weekly time step for an outlet capacity of Lohsa II of $7 \mathrm{~m}^{3} / \mathrm{s}$ (Reference), $5 \mathrm{~m}^{3} / \mathrm{s}$ (C5) and $3 \mathrm{~m}^{3} / \mathrm{s}$ (C3) for year 2022 of realization 4. a) Inflow; b) Outflow; c) Relative Storage Volume. 
To fulfil user needs when less water is supplied by the Lohsa II Reservoir, the water has to be released by other reservoirs, e.g. the Bautzen Reservoir, the Quitzdorf Reservoir and the Spremberg Reservoir at the expense of their storage content (fig. 6). For the Lohsa II Reservoir itself (fig. 6c)), it can be seen that constrained by the outlet capacity the outflow in week 22 is highest for the reference and lowest for the C3 scenario. For the C5 and the C3 scenario the reservoir content stays at an almost constant high level until week 22 . There is more water in the storage, in week 25 there is also a high outflow from the Lohsa II Reservoir in C3, which is not pronounced for the other scenarios. In week 22, high outflows from the Bautzen Reservoir and the Quitzdorf Reservoir counterbalance low outflows of the Lohsa II Reservoir in the scenarios C3 and C5 so that there is almost no difference in outflow of the Spremberg Reservoir despite only small differences in storage content. In week 23 the outflow of the Spremberg Reservoir is considerably reduced for C3.
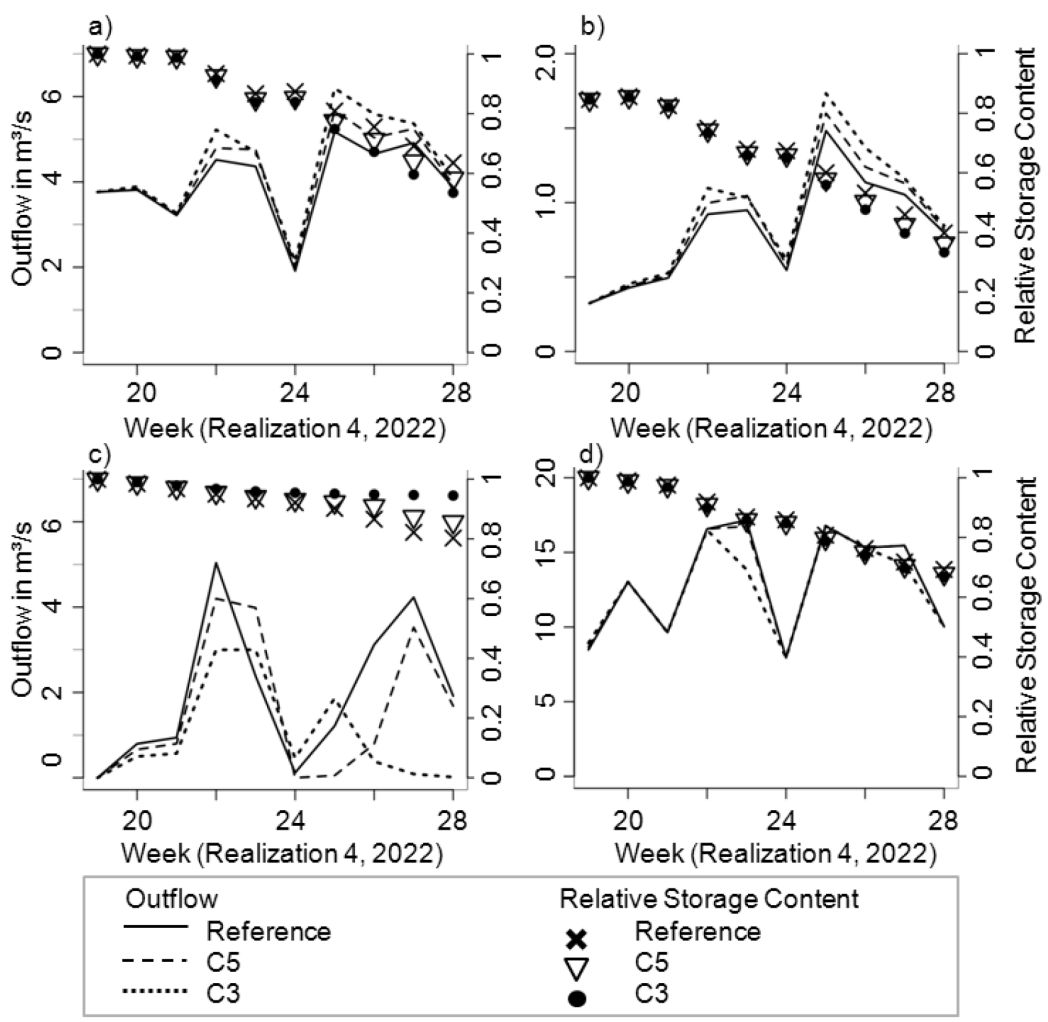

Figure 6: Outflow and relative storage content of the reservoirs for an outlet capacity of Lohsa II of $7 \mathrm{~m}^{3} / \mathrm{s}$ (Reference), $5 \mathrm{~m}^{3} / \mathrm{s}$ (C5) and $3 \mathrm{~m}^{3} / \mathrm{s}$ (C3) for the year 2022 of realization 4. a) Bautzen; b) Quitzdorf; c) Lohsa II; d) Spremberg. 
Thus, with a reduced outflow of the Spremberg reservoir, also the discharges at the gauges Cottbus, Leibsch and Grosse Traenke are reduced in the C5 and the C3 scenarios (fig. 7). Nevertheless, the differences between the different management scenarios are in the same order as those between monthly and weekly simulation time step.
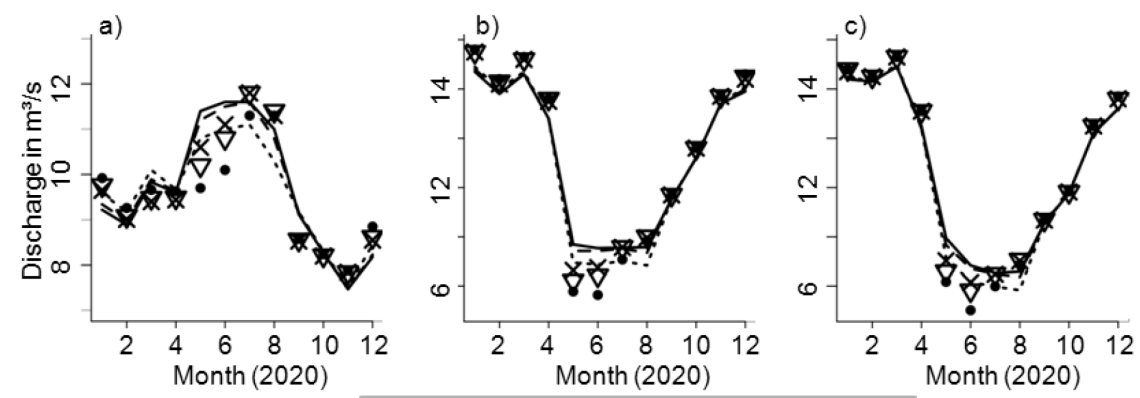

\begin{tabular}{|c|c|}
\hline $\begin{array}{ll}\text { Weekly time step } \\
\ldots & \text { Reference } \\
-\cdots & \text { C5 } \\
\cdots \cdots . . . & \text { C3 }\end{array}$ & $\begin{array}{l}\text { Monthly time step } \\
\times \text { Reference } \\
\nabla \text { C5 } \\
- \text { C3 }\end{array}$ \\
\hline
\end{tabular}

Figure 7: $\quad$ Average monthly managed discharges for the 5-year-period 2020 for monthly and weekly simulation for an outlet capacity of Lohsa II of $7 \mathrm{~m}^{3} / \mathrm{s}$ (Reference), $5 \mathrm{~m}^{3} / \mathrm{s}$ (C5) and $3 \mathrm{~m}^{3} / \mathrm{s}$ (C3) for the year 2022 of realization 4. a) Cottbus; b) Leibsch; c) Grosse Traenke.

\section{Conclusions and outlook}

As a consequence of increasing temperature and decreasing precipitation lower natural discharges are simulated in the study region. The differences in the natural discharges between the two hydrological models used, SWIM and EGMO are in the same order as those between the climate scenarios.

Due to a reduced groundwater depression cone and therefore a larger area of runoff contribution, managed discharges simulated with WBalMo increase for the first years of the simulation. From 2030 onward the managed discharges decrease due to declining natural discharges.

The refinement of the simulation time step influences managed discharges, especially in summer months when water is released from reservoirs to augment low flow discharges. The reduction of the outlet capacity of the Lohsa II Reservoir leads to less water being released per time step from this reservoir, which is mostly counterbalanced by releases from other reservoirs. That way, the water quality of the Spree River is not additionally impacted by high amounts of acidic water with high concentrations of iron and sulphate from the Lohsa II Reservoir. However, in most cases the effect of the reduced outlet capacity exacerbates the effect of more storage in summer so that this adaptation often leads to even lower summer discharges at downstream river sections. The differences between the simulation results under different time steps are in the 
same order as those of different management options of the Lohsa II Reservoir. In summer, the minimum discharge at gauge Grosse Traenke falls below the limit of $8 \mathrm{~m}^{3} / \mathrm{s}$ in both time steps and all management options.

As the impacts of climate change are not sufficiently mitigated by water management, further climate change adaptation measures have to be investigated. As the uncertainties regarding potential natural discharges related to the climate scenario and the hydrological model are remarkable, also natural discharges simulated by EGMO and SWIM driven by STAR $0 \mathrm{~K}$ and $3 \mathrm{~K}$ will be considered in WBalMo. Later, based on the managed discharges provided by WBalMo water quality modelling will be performed. Then the effects of a reduced outlet capacity of the Lohsa II reservoir can be assessed also in terms of water quality.

\section{Acknowledgements}

This work was carried out as part of the German Research Programme KLIMZUG, namely INKA BB, subproject 21, funded by the Federal Ministry of Education and Research (BMBF) and the Lusatian and Central German Mining Management Company (LMBV). The first author was supported by the Brandenburg Ministry of Science, Research and Culture as part of the International Graduate School at Brandenburg University of Technology.

\section{References}

[1] Vörösmarty, C.J., Green, P., Salisbury, J. \& Lammers, R.B., Global water resources: Vulnerability from climate change and population growth. Science, 289 (5477), pp 284-288, 2000.

[2] Loucks, D.P. \& Van Beek, E., Water Resources System Planning and Management, UNESCO: 2005.

[3] Stakhiv, E.Z., Managing Water Resources for Climate Change Adaptation (21). Adapting to Climate Change, eds. J.B. Smith, N. Bhatti, G.V. Menzhulin, R. Benioff, M. Campos, B. Jallow, F. Rijsberman, M. Budyko and R.K. Dixon, Springer New York: pp. 243-264, 1996.

[4] Frederick, K.D. \& Major, D.C., Climate Change and Water Resources. Climatic Change, 37 (1), pp 7-23, 1997.

[5] Wilby, R.L. \& Harris, I., A framework for assessing uncertainties in climate change impacts: Low-flow scenarios for the River Thames, UK. Water Resources Research, 42 (2), pp W02419, 2006.

[6] Gleick, P.H., Regional hydrologic consequences of increases in atmospheric $\mathrm{CO}_{2}$ and other trace gases. Climatic Change, 10, pp 137-161, 1987.

[7] Roeckner, E., Bäuml, G., Bonaventura, L., Brokopf, R., Esch, M., Giorgetta, M., Hagemann, S., Kirchner, I., Kornblueh, L., Manzini, E., Rhodin, A., Schlese, U., Schulzweida, U. \& Tompkins, A., The atmospheric general circulation model ECHAM 5. PART I: Model description, Max-Planck-Institute for Meteorology: 2003. 
[8] Werner, P.C. \& Gerstengarbe, F.W., Proposal for the development of climate scenarios. Climate Research, 8 (3), pp 171-182, 1997.

[9] Orlowsky, B., Gerstengarbe, F.-W. \& Werner, P.C., A resampling scheme for regional climate simulations and its performance compared to a dynamical RCM. Theoretical and Applied Climatology, 92 (3-4), pp 209223, 2008.

[10] Krysanova, V., Müller-Wohlfeil, D.I. \& Becker, A., Development and test of a spatially distributed hydrological water quality model for mesoscale watersheds. Ecological Modelling, 106 (2-3), pp 261-289, 1998.

[11] Krysanova, V., Wechsung, F., Arnold, J., Srinivasan, R. \& Williams, J., SWIM (Soil and Water Integrated Model) User Manual, Potsdam Institut für Klimafolgenforschung: Potsdam, pp. 239, 2000.

[12] Pfützner, B. \& Glos, E., Das Einzugsgebietsmodell EGMOD für wasserwirtschaftliche Planungen und Durchflußvorhersagen im Flachland der DDR. Wasserwirtschaft - Wassertechnik, pp H 7, 1986.

[13] Becker, A., The integrated hydrological catchment model EGMO. Hydrological Sciences Bulletin, 21 (1), 1976.

[14] Grünewald, U., Problems of integrated water management in the SpreeHavel region in the context of global change Integrated Analysis of the Impacts of Global Change on Environment and Society in the Elbe River Basin, eds. F. Wechsung, S. Kaden, H. Behrendt and B. Klöcking, Weissensee: Berlin, pp. 203-212, 2008.

[15] Huang, S.C., Krysanova, V., Österle, H. \& Hattermann, F.F., Simulation of spatiotemporal dynamics of water fluxes in Germany under climate change. Hydrological Processes, 24 (23), pp 3289-3306, 2010.

[16] Conradt, T., Koch, H., Hattermann, F.F. \& Wechsung, F., Spatially differentiated management-revised discharge scenarios for an integrated analysis of multi-realisation climate and land use scenarios for the Elbe River basin. Regional Environmental Change, pp 1-16, 2012.

[17] Pohle, I., Koch, H. \& Grünewald, U., Potential climate change impacts on the water balance of subcatchments of the River Spree, Germany. Advances in Geosciences, 32, pp 49-53, 2012.

[18] Pohle, I., Gädeke, A., Koch, H. \& Grünewald, U., Abschätzung möglicher Folgen des Klimawandels auf die regionalen Wasserressourcen der Lausitz Wasserressourcen im globalen Wandel. Hydrologische Grundlagen - von der Messung zur Anwendung. , eds. R. Weingartner and B. Schädler, Bern, 2013.

[19] Koch, H., Kaltofen, M., Schramm, M. \& Grünewald, U., Adaptation strategies to global change for water resources management in the Spree river Catchment, Germany. International Journal of River Basin Management, 4 (4), pp 273-281, 2006.

[20] Kaden, S., Schramm, M. \& Redetzky, M., ArcGRM: interactive simulation system for water resources planning and management in river basins Research basins and hydrological planning, eds. R.Z. Xi, W.Z. Gu and K.P. Seiler, Taylor \& Francis: London, UK, pp. 185-192, 2004. 
[21] Kaden, S., Schramm, M. \& Redetzky, M., Large-scale water management models as instruments for river catchment management Integrated Analysis of the Impacts of Global Change on Environment and Society in the Elbe Basin, eds. F. Wechsung, S. Kaden, H. Behrendt and B. Klöcking, Weißensee Verlag: Berlin, pp. 217-227, 2008.

[22] Koch, H., Kaltofen, M., Grünewald, U., Messner, F., Karkuschke, M., Zwirner, O. \& Schramm, M., Scenarios of water resources management in the Lower Lusatian mining district, Germany. Ecological Engineering, 24 (1-2), pp 49-57, 2005.

[23] Dietrich, O., Koch, H. \& Schweigert, S., Water resources management - a possibility for drought mitigation in wetlands. WIT Transactions on Ecology and the Environment, 103, pp 53-62, 2007.

[24] Kaltofen, M., Koch, H., Schramm, M., Grünewald, U. \& Kaden, S., Anwendung eines Langfristbewirtschaftungsmodells für multikriterielle Bewertungsverfahren - Szenarien des globalen Wandels im bergbaugeprägten Spreegebiet. Hydrologie und Wasserbewirtschaftung, 48 (2), pp 60-70, 2004. 